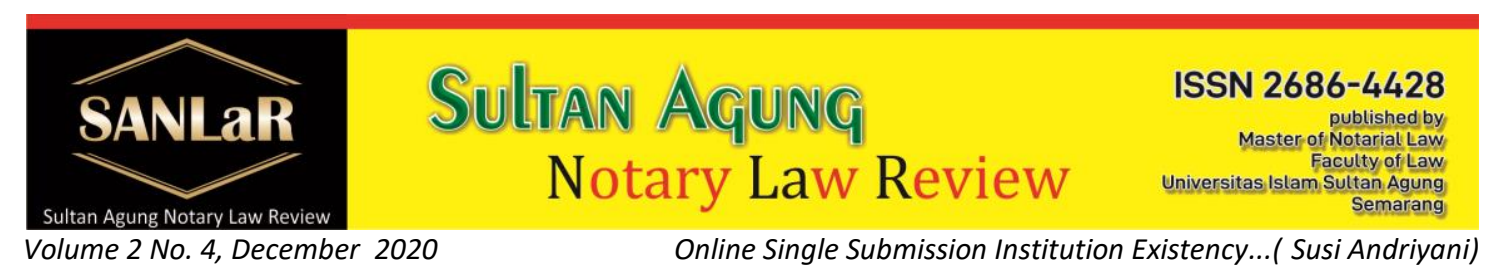

\title{
Online Single Submission Institution Existency in Land Technical Considerations
}

\author{
Susi Andriyani ${ }^{*}$ and Ira Alia Maerani ${ }^{* *}$ \\ *) Students of Master of Notary Law, Universitas Islam Sultan Agung (UNISSULA) \\ Semarang, E-mail: susiandriyani1969@gmail.com \\ $\left.{ }^{* *}\right)$ Lecturer of Master of Notary Law, Universitas Islam Sultan Agung (UNISSULA) \\ Semarang
}

\begin{abstract}
The enactment of Government Regulation Number 24 of 2018 which introduces the existence of an Online Single Submission (OSS) institution has brought many changes in various fields, one of which is in the field of land services. This study analyzes the implementation of land technical considerations through the OSS institution and the constraints in implementing land technical considerations through the OSS institution. The research method used is normative legal research with a statutory approach and a conceptual approach. The results show that the implementation of land technical considerations through the OSS institution is aimed at providing convenience in processing permits in order to improve the investment climate in Indonesia.
\end{abstract}

Keywords: Licensing; Land Technical Considerations; OSS.

\section{Introduction}

Improving investment licensing in Indonesia is a homework which seems to have never been done properly. The bureaucracy of business licensing often creates high costs in the business world, because of the illegal costs involved in processing business licensing. This certainly greatly affects the investment climate in Indonesia. ${ }^{1}$

In recent years, the flow of world globalization has become increasingly rapid. This makes the investment climate improve as well. The ease of doing business in a country will make investors come and invest. One of the indicators used to assess Indonesia's competitiveness is the ease of investment. An important step that needs to be taken for ease of doing business is to carry out regulatory reforms related to investment or business in Indonesia. Regulatory reform is one of the important agendas that Indonesia needs to do, to improve the quality of regulations (high-quality regulations). ${ }^{2}$ One of the strategies that the government has taken to support the ease of doing business in Indonesia is the issuance of Government Regulation Number 24 of 2018

\footnotetext{
${ }^{1}$ Sembiring, Sentosa. (2018). Hukum Investasi. Bandung: Nuansa Aulia. p. 106

2 Mayasari, Ima. " Evaluasi Kebijakan Izin Lokasi dan Pertimbangan Teknis Pertanahan Pasca Penerapan Online Single Submission", Journal of Rechtsvinding, Vol. 8 No. 3, December 2019, p. 404
} 
concerning Electronically Integrated Business License Services (PP No. 24 Th. 2018). Article 1 number 5 PP No. 24 of 2018 states that Electronically Integrated Business Licensing or Online Single Submission (OSS) is a Business License issued by the OSS Institution for and on behalf of ministers, institutional leaders, governors, or regents/mayors to Business Actors through an integrated electronic system. Meanwhile, what is meant by the OSS Institution is mentioned in Article 1 number 11 PP No. 24 Years. 2018 as follows:

The transformation of technological advances has made Indonesia enter a disruption era, where innovation is very important. This technological development also influences the laws and regulations governing business licensing in Indonesia. ${ }^{3}$ The implementation of the OSS system is intended to catch up with Indonesia in facilitating licensing services from neighboring countries such as Vietnam, Malaysia and Singapore. With the promulgation of PP. 24 Years. 2018, of course, fundamentally changed the permit issuance system in Indonesia. OSS is intended to make it easier for business actors to obtain legality. Trimming the old procedure where at first the applicant for a permit met the requirements before getting a business license, now through OSS, business actors are given easy information and clear procedures in various stages. ${ }^{4}$

The enactment of PP No. 24 Years. 2018 which introduced the OSS institution brought many changes in various fields, one of which was in the field of land services. The Minister of Agrarian and Spatial Planning/Head of the National Land Agency responds to the implementation of Online Single Submission (OSS) by issuing a Regulation of the Minister of Agrarian and Spatial Planning/Head of the National Land Agency Number 15 of 2018 concerning Technical Considerations for Land (Permen ATR/Ka.BPN No.15 Th 2018) and updated the regulations regarding location permits through the Regulation of the Minister of Agrarian Affairs and Spatial Planning/Head of the National Land Agency Number 17 of 2019 concerning Location Permits (Pemen ATR/Ka.BPN No. 17 Th. 2019).

\section{Research Methods}

This research is a nomative legal research (doctrinal legal research). As with the type of normative research, the approach method used in this research is the statute approach and the conceptual approach. ${ }^{5}$ Research sources can be divided into primary, secondary, and tertiary sources of law. The collection of legal materials is carried out by means of library research (library research). ${ }^{6}$ The results of the analysis of legal

\footnotetext{
3 Isnaini, Hatta.Wahyu Utomo, " Tantangan Pelaksanaan Jabatan Notaris Di Era Revolusi Industri 4.0", Paper, delivered in the Public Lecture of the Master of Notary at Universitas Narotama Surabaya, September 2019, p. 2

${ }^{4}$ Desi Arianing Arrum, " Kepastian Hukum Dalam Perizinan Berusaha Terintegrasi Secara Elektronik (Online Single Submission) di Indonesia", Journal of Juris-Diction, Vol. 2 No. 5, September 2019, p. 1635

${ }^{5}$ Pasek Diantha, I Made. (2016). Metodologi Penelitian Hukum Normatif. Jakarta: Prenada Media Group. p. 156

6 Soekanto, Soerjono dan Sri Mamudji. (1985). Penelitian Hukum Normatif. Jakarta: Rajagrafindo Persada. p. 41
} 
materials will be interpreted using systematic and grammatical interpretation methods. $^{7}$

\section{Results and Discussion}

One of Nawa Cita's agendas mandates that Indonesia can become an economically independent and competitive nation. Increasing economic competitiveness through a conducive investment climate is one of Indonesia's national priorities as stated in the 2015-2019 National Medium-Term Development Plan (RPJMN 2015-2019)..$^{8}$ The emphasis on improving economic competitiveness needs to be directed, one of which is to improve the investment climate and business climate, and to achieve this agenda, the government has made various efforts, one of which is issuing various deregulation packages in the economic sector to increase competitiveness and economic growth. Apart from upholding and guaranteeing legal certainty, the goal of deregulation is to simplify the bureaucratic process that can have a positive impact on competitiveness, ease of doing business and economic growth.

The ranking of ease of doing business, published by the World Bank, in the Doing Business Measuring Business Regulations, Ranking and Ease of Doing Business in 2019, Indonesia is ranked 73 (seventy three) in the Ease of Doing Business Rank. Meanwhile, in Starting a Business, Indonesia is ranked 134 (one hundred and thirty four)..$^{9}$ In the investment sector, each sector has arrangements for a licensing mechanism in the investment sector opened in Indonesia. Business licenses issued by ministries or agencies and local governments to initiate, implement and develop business activities face problems related to their implementation. Restructuring regulations that support accelerated implementation is important to reduce barriers to developing business activities.

In general, it can be said that the quantity or number of laws and regulations in the business sector is not proportional, and even tends to be over-regulated. Almost every agency whose duties and functions are related to the sector try to form regulations and in the formation of these regulations do not coordinate with each other and instead promote their respective sectors. In addition, the legislators cannot/want to realize that the formation of laws and regulations is actually a process of uniting or harmonizing various interests. Based on the above conditions, it can be said that the laws and regulations in the business sector cannot function optimally. ${ }^{10}$

Ida Bagus Rahmadi Supancana stated that there are 3 functions of regulation, namely: a) As a means of order or behavior guidelines, ie regulations serve as guidelines for the implementation of social dynamics, in this case both formal and informal activities; $b$ ) As a development instrument, ie regulation moves resources to achieve a

\footnotetext{
${ }^{7}$ Mertokusumo, Sudikno. (2005). Penelitian Hukum. Yogyakarta: Liberty. p. 47

8 BAPPENAS. (2014). Rencana Pembangunan Jangka Menengah Nasional 2015-2019. Buku I, Jakarta: Agenda Pembangunan Nasional. p. 44

9 The World Bank, "Doing Business Measuring Business Regulations", https://www.doingbusiness.org/, accessed 17 August 2019

10 Wicipto Setiadi, ", "Simplifikasi Peraturan Perundang-Undangan Dalam Rangka Mendukung Kemudahan Berusaha", Jurnal Rechstvinding, Vol. 7 No. 3, December 2018, p. 324
} 
predetermined goal; and c) As an integration factor, ie regulation integrates areas and policies in the framework of state administration and development into a National Regulatory System which is an aggregation of all existing regulations. ${ }^{11}$

In a modern state of law, the task and authority of the government is not only to maintain order and security (rust en orde), but also to strive for public welfare (bestuurszorg). In order to realize the government's duties and authorities, the law gives regulatory authority to the government. Based on this regulatory function, juridical instruments emerge in the context of dealing with individual and concrete events, namely in the form of provisions. One form of this provision is permission. ${ }^{12}$

Permit (vergunning) based on the concept in Act No. 30 of 2014 concerning Government Administration (Law No. 30 of 2014) is a decision of an authorized government official as a form of approval of requests from citizens in accordance with statutory provisions. Permission is meant by the legislator's desire to achieve a certain order or to block bad conditions. The aim is to regulate actions which legislators do not consider entirely despicable, but want to be able to exercise modest supervision. In a narrow sense, the concept of licensing is that actions are prohibited, unless permitted with the aim that in the provisions connected with permission, certain limits are given for each case. ${ }^{13}$

The OSS system came into effect on July 92018 and was inaugurated by Coordinating Minister for Economic Affairs. The Electronically Integrated Business Licensing Service (PBTSE), which is more easily referred to by the generic name OSS, is present in the framework of business licensing services applicable to all Ministries, Institutions and Regional Governments throughout Indonesia, which has been carried out through One Stop Integrated Licensing ( PTSP). Apart from using PTSP, the public can access the OSS system online anywhere and anytime. OSS is the government's effort to simplify business licensing and create an integrated licensing service model that is fast and cheap, and provides certainty.

The OSS system provides various benefits, including: a) msimplify the management of various business licenses, both prerequisites for doing business (permits related to location, environment, and buildings), business permits, as well as operational permits for business operations at the central or regional level with a mechanism to fulfill the commitment to permit requirements; b) mfacilitate business actors to connect with all stakeholders and obtain permits safely, quickly and in real time; c) mfacilitate business actors in reporting and solving licensing problems in one place; and d) mfacilitate business actors to store licensing data under one business identity (NIB).

The authority to issue business permits is regulated in Article 18 PP No. 24 Years. 2018 which states that the business license is issued by the minister, head of institution, governor, or regent/mayor according to their authority. Furthermore, in Article 19 PP. 24 Years. 2018 stated that the implementation of the authority to issue business

\footnotetext{
11 Ida Bagus Rahmadi Supancana, "Better Regulations Tools in Policy Formulation", Makalah, disampaikan dalam kerja sama antara Pusat Kajian Regulasi (Center For Regulatory Research), The World Bank, Swiss Confederation, Kingdom of the Netherlands, dan Kementerian Perekonomian, Bandung, 2526 September 2017. p. 3

${ }^{12}$ Arrum, Desi Arianing. Op.Cit., p. 1645

13 M. Hadjon, Philipus. Ed. (1993). Pengantar Hukum Perizinan. Surabaya: Yuridika. p. 3
} 
licenses as referred to in Article 18 including the issuance of other documents related to business licensing must be carried out through the OSS Institution. (Article 19 PP No. 24 Year 2018). This means that the OSS Institute issues business licenses for and on behalf of ministers, institutional leaders, governors, or regents/mayors. ${ }^{14}$

This regulation is in accordance with the legality principle which states that government authority comes from statutory regulations. The principle of legality is the basis for the legitimacy of government action and guarantees the protection of people's rights. In other words, every state and government administration must have the principle of legitimacy. The application of the legality principle will support the enforcement of legal certainty and equal treatment. Without a basis of authority granted by a valid statutory regulation, all kinds of government officials will not have the authority to influence or change the situation or legal position of their citizens. ${ }^{15}$ In land services regarding technical considerations of land, it is also carried out through the OSS institution in line with the enactment of the Regulation of the ATR/Ka.BPN No. 15 years old 2018. As for the ratio legislation for the issuance of Permen ATR/Ka.BPN No. 15 years old 2018 is to support the implementation of the provisions of PP No. 24 Years. 2018 so that the adjustment of Land Technical Consideration services is made. In Article 1 number 1 Permen ATR/Ka.BPN No. 15 years old 2018 states that Land Technical Considerations are considerations that contain the terms and conditions of control, ownership, use and utilization of land with due regard to spatial suitability.

The objectives of the adjustment of Land Technical Consideration services include: a) accelerating and improving the quality of investment and business services; b) realizing the use and utilization of land in an efficient, effective and sustainable manner; c) achieve a balance between land capabilities, use and utilization of land and the environment; d) realizing just control and ownership of land; e) realizing the designation, use and utilization of land in accordance with the Spatial Plan; and $f$ ) realizing the control, ownership, use and utilization of land based on a sustainable, optimal, harmonious and balanced basis in rural areas as well as in a safe, orderly, smooth and healthy urban area based on the Spatial Plan.

In Article 4 Permen ATR/Ka.BPN No. 15 years old 2018 determined that Land Technical Considerations are given in the context of: a) approval/rejection of Location Permits; b) granting/extending or renewing land rights; c) affirmation of the status and recommendation of land ownership; or d) changes in land use and utilization. Of the four criteria above, until now the technical considerations for land through oSS institutions are still limited to the approval/rejection of a location permit.

The subject of land technical considerations in the framework of approval or rejection of a location permit shall be given to individual or non-individual business actors. Individual business actors are individual Indonesian residents who are capable of acting and taking legal actions. Meanwhile, non-individual Business Actors consist of: a) limited liability companies; b) public companies; c) regional public companies; d)

\footnotetext{
${ }^{14}$ Monika Suhayati, "Permasalahan Perizinan Berusaha Terintegrasi Secara Elektronik (Online Submission System)", Jurnal Info Singkat, Pusat Penelitian Badan Keahlian DPR RI, Vol. X No. 23, Desember 2018, p. 3

15 Ridwan, Juniarso dan Achmad Sodik Sudrajat.(2012). Hukum Administrasi Negara dan Kebijakan Pelayanan Publik. Bandung: Nuansa. p. 133-137
} 
other legal entities owned by the state; e) public service agencies; f) broadcasting institutions; $g$ ) a business entity established by a foundation; and h) cooperatives.

For a location permit application, the applicant must also attach the following requirements: a) Business Identification Number; b) Decision to Issue Location Permits and Attachments; c) Statement of Commitment Fulfillment or No Commitment; d) Map containing polygon coordinates of location boundaries; e) Business activity plan or land use and utilization plan; and f) A statement regarding the location and area of land which is already controlled by the business actor and other business actors who are part of the same group.

The technical consideration process for land is carried out by going through the process of submitting an application file at the service counter/OSS, then the Land Technical Advisory Team carries out a site survey, data processing and analysis, discussion meetings, preparation of minutes and maps, and determination, for which the Head of the Land Office provides technical considerations land extension which is then conveyed to the Regent/Mayor/Ka. PTSP to get a decision to approve/reject a location permit.

OSS brings a breakthrough automatic approval that uniform requirements and there is no need for a document review process as long as it meets the administrative requirements on the portal, then you will immediately get a business license. The fundamental difference between OSS and the previous licensing system is that initially in the licensing system the permit applicant met the requirements first, then getting a business license now through OSS the permit applicant obtained a business license first then completing the requirements.

Changes that occur in connection with the application of technical considerations for land through OSS can be seen from the aspect of its position. Previously, in the Regulation of the Head of the National Land Agency Number 2 of 2011 (Perkaban No.2 of 2011), technical considerations of land were issued before the location permit was issued by PTSP/Bupati/Walikota, and became a consideration in issuing location permits. ${ }^{16}$ Whereas in the Permen ATR/Ka.BPN No. 15 years old 2018, granted after the location permit is issued by the OSS Institute and as a basis for consideration of the effective location permit. Then in the issuance procedure, location permits are issued through OSS for Business Actors. The implementation period was shorter from 14 (fourteen) days to 10 (ten) days. Furthermore, it is related to authority without being carried out in stages, meaning that currently it is only processed through the Regency/City Land Office.

The use of the OSS system in Land Technical Considerations is carried out by taking into account the Computerization of Land Activities (KPP). Mentioned in Article 1 number 10 Permen ATR/Ka.BPN No. 15 years old 2018 that KKP is the main application in supporting the implementation of the authority, duties and functions of the Ministry of Agrarian Affairs and Spatial Planning/National Land Agency based on information and communication technology that was built and developed referring to the flow, requirements, time, costs, and authority in accordance with the provisions of laws and regulations. invitation.

${ }^{16}$ Mayasari, Ima. Op.Cit., p. 407 
The problems that occur with the use of the OSS system in Land Technical Considerations are related to not all Land Offices in Indonesia using this application. There are still certain areas that are far from big cities and do not yet have quality internet connections that have not used the KPP application. The occurrence of these conditions in Article 18 Permen ATR/Ka.BPN No. 15 years old 2018 has stipulated that if the Land Office has not used the KKP, notification of the completeness of the required documents and/or receipt of the application can be done directly without going through the OSS system.

\section{Closing}

\subsection{Conclusion}

Implementation of Land Technical Considerations is carried out through the OSS institution to provide convenience in processing permits in order to improve the investment climate. Land Technical Considerations which have been implemented through the OSS system since the enactment of the ATR/Ka Regulation. BPN No. 15 years old 2018, however, currently it is only limited to the application for location permits that can be done through OSS institutions.

The obstacle that exists in using the OSS system in Land Technical Considerations at this time is that not all Land Offices in Indonesia have used this application. There are still certain areas that are far from big cities and do not yet have quality internet connections that have not used the KPP application. Due to this condition, the application for a location permit can still be carried out manually by coming directly to the local Land Office.

\subsection{Suggestion}

In the future, regarding the granting/extension or renewal of land rights, confirmation of status and recommendations for land tenure arising and changes in land use and utilization also need to be carried out through the OSS system. In addition, it is also necessary to equalize the integration of the OSS system with KPPs at Land Offices throughout Indonesia so that in the future there is no need for manual applications. This is also aimed at avoiding extortion which can hinder investment in Indonesia.

\section{References}

\section{Journals:}

[1] Desi Arianing Arrum, " Kepastian Hukum Dalam Perizinan Berusaha Terintegrasi Secara Elektronik (Online Single Submission) di Indonesia", Journal of JurisDiction, Vol. 2 No. 5, September 2019

[2] Ida Bagus Rahmadi Supancana, "Better Regulations Tools in Policy Formulation", Makalah, disampaikan dalam kerja sama antara Pusat Kajian 
Regulasi (Center For Regulatory Research), The World Bank, Swiss Confederation, Kingdom of the Netherlands, dan Kementerian Perekonomian, Bandung, 25-26 September 2017. p. 3

[3] Isnaini, Hatta.Wahyu Utomo, " Tantangan Pelaksanaan Jabatan Notaris Di Era Revolusi Industri 4.0", Paper, delivered in the Public Lecture of the Master of Notary at Universitas Narotama Surabaya, September 2019

[4] Mayasari, Ima. " Evaluasi Kebijakan Izin Lokasi dan Pertimbangan Teknis Pertanahan Pasca Penerapan Online Single Submission", Journal of Rechtsvinding, Vol. 8 No. 3, December 2019

[5] Monika Suhayati, "Permasalahan Perizinan Berusaha Terintegrasi Secara Elektronik (Online Submission System)", Jurnal Info Singkat, Pusat Penelitian Badan Keahlian DPR RI, Vol. X No. 23, Desember 2018, p. 3

[6] Wicipto Setiadi, ", "Simplifikasi Peraturan Perundang-Undangan Dalam Rangka Mendukung Kemudahan Berusaha", Jurnal Rechstvinding, Vol. 7 No. 3, December 2018, p. 324

Books:

[1] BAPPENAS. (2014). Rencana Pembangunan Jangka Menengah Nasional 20152019. Buku I, Jakarta: Agenda Pembangunan Nasional.

[2] M. Hadjon, Philipus. Ed. (1993). Pengantar Hukum Perizinan. Surabaya: Yuridika.

[3] Mertokusumo, Sudikno. (2005). Penelitian Hukum. Yogyakarta: Liberty.

[4] Pasek Diantha, I Made. (2016). Metodologi Penelitian Hukum Normatif. Jakarta: Prenada Media Group.

[5] Ridwan, Juniarso dan Achmad Sodik Sudrajat.(2012). Hukum Administrasi Negara dan Kebijakan Pelayanan Publik. Bandung: Nuansa.

[6] Sembiring, Sentosa. (2018). Hukum Investasi. Bandung: Nuansa Aulia.

[7] Soekanto, Soerjono dan Sri Mamudji. (1985). Penelitian Hukum Normatif. Jakarta: Rajagrafindo Persada.

Internet:

The World Bank, "Doing Business Measuring Business Regulations", https://www.doingbusiness.org/, accessed on 17 August 2019 


\section{Regulation:}

[1] Act No. 30 of 2014 concerning Government Administration

[2] Government Regulation Number 24 of 2018 concerning Electronically Integrated Business License Services

[3] Ministerial regulation Agrarian Affairs and Spatial Planning/Head of the National Land Agency Number 15 of 2018 concerning Land Technical Considerations

[4] Ministerial regulation Agrarian Affairs and Spatial Planning/Head of the National Land Agency Number 17 of 2019 concerning Location Permits 